This item was submitted to Loughborough's Research Repository by the author.

Items in Figshare are protected by copyright, with all rights reserved, unless otherwise indicated.

\title{
International migration and the rise of the 'civil' nation
}

PLEASE CITE THE PUBLISHED VERSION

http://dx.doi.org/10.1080/1369183X.2016.1155980

\section{PUBLISHER}

(C) Taylor \& Francis (Routledge)

\section{VERSION}

AM (Accepted Manuscript)

\section{PUBLISHER STATEMENT}

This work is made available according to the conditions of the Creative Commons Attribution-NonCommercialNoDerivatives 4.0 International (CC BY-NC-ND 4.0) licence. Full details of this licence are available at: https://creativecommons.org/licenses/by-nc-nd/4.0/

\section{LICENCE}

CC BY-NC-ND 4.0

\section{REPOSITORY RECORD}

Antonsich, Marco. 2019. "International Migration and the Rise of the 'civil' Nation". figshare. https://hdl.handle.net/2134/20468. 


\title{
International migration and the rise of the 'civil' nation
}

\author{
Marco Antonsich, Loughborough University
}

\begin{abstract}
:
Scholars largely agree that immigration policies in Western Europe have switched to a liberal, civic model. Labelled as 'civic turn', 'civic integration' or 'liberal convergence', this model is not identically applied across countries, since national institutions, traditions, and identifications still matter. Even so, the main focus is on processes which allow or prevent migrants to be incorporated into nations usually taken for granted in their meanings. Moving from policies to discourses, this article aims to interrogate what kind of nation is behind these policies as a way to further scrutinize the 'civic turn'. Exploring how the term 'civility' and its adjectivizations are discursively deployed in Italian parliamentary debates on immigration and integration issues, the article points to two opposite narratives of nation. While one mobilizes civility in order to rewrite the nation in terms of a common, inclusive, civic 'we', the other uses civility to reaffirm the conflation between national identity and the identity of the ethno-cultural majority. These findings suggest the importance of exploring the 'civic turn' not only across countries, but also across political parties within the same country to capture the ways in which a liberal, civic convergence in political discourses might hide divergent national boundary mechanisms.
\end{abstract}

Key-words: civic turn, civility, ethnic, nation, immigration, Italy 


\section{Introduction}

It is widely acknowledged that the ways Western European countries address issues of immigrant integration today point to a liberal, civic model. Variously labelled as the 'civic turn' (Mouritsen 2008), 'civic integration' (Joppke 2007, Goodman 2010), or 'liberalconvergence' (Mouritsen and Olsen 2013), this approach signals a move away from a past of both multicultural policies (Joppke 2004) and 'old-style nationalist' assimilation (Mouritsen 2008). In fact, the new civic model of immigrant integration avoids dealing with cultures and communities, focusing instead on individuals (Goodman and Wright 2015). The target is the single migrant who, in a neoliberal logic of individual autonomy, is responsible for her/his own integration (Matejskova 2013, Türken et al. 2015). 'Earned citizenship' (Andreouli and Stockdale 2009, Faist 2009, Van Houdt et al. 2011) has become the new mantra of societies which have somewhat switched from an ideal of collective citizenship to one of individualized citizenship (Sparke, 2006). In this passage, the nation has also become increasingly 'political' or 'civic', turning apparently its back to the old, traditional Kulturnation (Mouritsen 2008).

The present article aims to scrutinize further this 'civic turn', by adopting a different analytical angle. My focus, in fact, is not on policies aimed at making immigrants 'attuned' to the national mainstream, but on how immigration triggers a rethinking of the national mainstream. I am interested in the transformative power international immigration exercises on perceptions of a national 'we' rather than on measures nation-states adopt to make 'them' national (although the two are obviously related). In this sense, I move the focus away from policy measures countries have adopted for incorporating an increasingly diverse population to the impact this population has had on the national imaginaries of these countries. In other words, my way of interrogating the 'civic' aspect responds more to a query on the ideational 
dimension behind integrationist measures than on their actual content, as it is instead prevalent in studies engaging with the civic turn. My argument is that a focus on the selfrepresentation of the receiving nations would further refine our understanding of the civic integrationist turn.

To this end, the article analyses the discursive use of the term 'civility' and its adjectivization in Italian parliamentary debates concerning immigration issues between 1986 and 2014. Being a country that has experienced immigration fairly recently and within a relatively short time period (Colombo and Sciortino 2004), Italy offers rich empirical materials as well as the opportunity to expand the research scope beyond conventional case studies (e.g., UK, Denmark, the Netherlands, Germany and France). The focus on 'civility' (civiltà) rather than 'civic-ness' is a data-driven choice, as civility and its adjectivized forms were most frequently used in Italian parliamentary debates. Theoretically, the relevance of this choice relies on the fact that civility is regarded as a key component of the 'civic turn' (Mouritsen 2008: 4).

Before analysing the parliamentary debates, the article offers a more reasoned discussion of the 'civic turn', introduces the notion of civility, and discusses the latter in relation to relevant nationalism theories. The methodological section details the data collection process, while also offering contextual information for the chosen case study. The analysis of the empirical materials is organized in two sections, dealing respectively with the narratives of the political 'left' and the political 'right'. These labels are mere shortcuts for more complex and contrasting political views and here adopted for the purposes of brevity. Findings point to the use of civility by the political right as a cultural boundary mechanism to preserve the conflation between the identity of the majority group and national identity, whereas the political left deploys civility as a political principle to rewrite the nation in more 
inclusive terms. The conclusion reflects on the implications of these findings for the current debate on the 'civic turn'.

\section{Civic integration, civility and the civic-ethnic divide}

The liberal-civic integrationist model can be described as a series of courses, tests, and contracts aimed at 'integrating' third-country nationals into the shared values and political principles of the receiving society (Goodman 2010, Larin 2015). According to Joppke (2007: 3), these principles are largely informed by Rawls's (1993) political liberalism, which emphasizes social justice, tolerance, equality, and civility. Interestingly, civic integration does not imply for Joppke that the nation is giving way to a new post-national condition. Rather, what he sees at work is the de-ethnicization of the nation or, in other words, its transformation from an ethno-cultural into a civic construct, along the lines of Habermas' constitutional patriotism, with the predominance of 'the political' over 'the cultural'(Joppke and Morawska 2003: 18-19, Joppke 2008: 535). This civic integration model - Joppke (2010) maintains - is spreading across Europe, as specific national models of immigrant integration yield to a universalistic model of liberal convergence. ${ }^{1}$

Both the civic integrationist turn and Joppke's reading of it have not escaped scrutiny. Two major criticisms are worth mentioning here. First, contrary to Joppke's influential argument, empirical evidence points to the continuing relevance of national institutional settings, traditions, and identifications in shaping the ways immigrants are incorporated into the receiving societies (Koopmans et al. 2005, Favell 2006, Jacobs and Rea 2007, Goodman 2012, Mouritsen 2012, Alba and Foner 2014). The present article also seems to support this latter view. Second, scholars have also challenged the 'liberal-ness' of the civic integrationist 
turn, suggesting that it still embodies a form of ethno-centric nation-politics aimed at drawing lines of inclusion/exclusion (Mouritsen 2006, Lægaard 2007, Kostakopoulou 2010, Jensen 2014, Larin 2015).

To better understand this latter criticism, it is worth recalling the very distinction between 'civic' and 'ethnic' - an old trope in the literature on nationalism. Formally theorized by Kohn (1945), but already present in earlier historical debates (Özkirimli 2003), this distinction aims to capture nationalism's different historical formations. Kohn saw the emergence of its civic variation in the West as a liberal achievement produced by the state, whereas ethnic nationalism was the typical trait of the non-Western world, trapped in prepolitical ethnic divisions (Antonsich 2015: 300). This distinction has then been further refined by various authors, in particular Smith (1986), who heralded it as a theoretical idealtype. While the civic nation stands for a political-legal community of citizens sharing a common civic culture, the ethnic nation stands for a community of common descent (Smith 1991: 11). For this reason, while the civic nation is supposedly liberal, voluntarist, universalist, and inclusive, the ethnic nation is supposedly illiberal, ascriptive, particularist, and exclusive (Brubaker 1999: 56).

The civic/ethnic dichotomy has been widely criticised as empirically flawed and analytically problematic (Xenos 1996, Yack 1996, Brubaker 1999). The main criticism relates to the fact that 'civic' and 'ethnic' are intertwined in almost all existing nationalisms (Smith 1991, Kuzio 2002, Özkirimli 2003, Calhoun 2007). As Kymlicka (2001: 24) observes, any state, however civic it might present itself, embodies the cultural values and practices of the dominant group (see also Bauböck 2002 and Bader 2005).

Building on this criticism, scholars have thus questioned the cultural and political 'neutrality' of the civic integration model, as mentioned above. Mouritsen (2008: 12), for instance, has aptly remarked that this model operates with two opposite essentialized 
cultures: on the one hand, the civil and progressive culture of the majority group, filled with principles of civility, tolerance, equality and rationality and, on the other hand, the regressive and backward culture of the minority groups, characterised by traditions, parochialism, and particularities. The public sphere in a civic nation is supposedly one which is purified by all these latter 'thick' features - a 'thin' space of liberal universal principles which finds in citizenship rather than identity its founding rationale.

In other words, despite its purportedly inclusive aspiration, the integrationist logic might carry the seeds of exclusion. Gressgard (2010: 10) rightly notes that the deculturalization of 'us' through the culturalization of 'others' makes immigrant integration into a civic, liberal moral sphere impossible. Similarly, Kymlicka (2011: 292) states that the majority group's claim of the public sphere as culturally and ethnically neutral is a stratagem for delegitimising the cultural-ethnic claims of minorities. In sum, the civic, liberal national space hides a particularistic cultural definition of who can be a 'proper' citizen (Calhoun 2007: 42).

To his credit, Joppke (2008: 541) acknowledges that the liberalism of the civic turn might transmute from a procedural framework into a substantive way of life. In the illuminating image of Mouritsen (2008: 6), it is 'thinness' that 'thickens', since a political principle (liberalism) becomes a cultural principle around which a national community defines itself. This nationalisation of liberal principles (Lægaard 2007) or culturalisation of politics (Mouritsen 2008, Kostakopoulou 2010) reveals for Zimmer (2003) the importance of moving beyond the ethnic/civic distinction. What matters for him is not the actual content of national discourses, but the ways in which this content is mobilized for purposes of inclusion/exclusion (see also Jensen 2014). Thus, for instance, Halikiopoulou et al. (2013) have shown how liberal-democratic values figure prominently in the discursive toolkit of radical right parties. Yet, these are appropriated as 'our' values and mobilized to portray 
migrants as those who undermine them, thus reinforcing the national boundary which defines the majority group (see also Antonsich 2012; Larin 2015; Jensen 2014).

These same contradictions seem also to characterize the notion of 'civility', which is indeed a key component in the framing of the civic nation. In the genealogical interpretation of Elias (1939 [2000]), civility marks the internalization of new standards of conduct at a time in history when the modern state acquires the monopoly of physical violence (White 2006: 447). This new conduct is predicated on the self-constraint of the individual, i.e. on the control and moderation of her/his emotions, affects, and desires (Rucht 2011: 394). The domestication of what is perceived as the rude nature of human beings becomes in time the defining trait of the upper class vis-à-vis lower classes. Moreover, moving from the individual to the societal register and from the domestic to the external scale, civility also comes to distinguish European societies from their 'primitive', 'barbarian' colonies, thus justifying their civilizing missions and imperialisms (White 2006, Baumgarten et al. 2011, Nehring 2011).

Despite its morally tainted past and a present in which this notion can still be mobilized in exclusionary terms (Lattas 2007, Antonsich 2012), civility has recently been rescued by various liberal authors as a guiding principle in the negotiation of diversity within pluralist societies (Baumgarten et al. 2011). For Rawls (1993), the ‘duty of civility’ prescribes what we can and ought to say in public discussions in ways which convey respect and commitment to collective reasoning (Brown 2003, Zurn 2013). In the conservative view of Shills (1997), civility is a pre-political virtue essential for a free, ordered, and liberal democratic society. For Barber (1984), civility is what promotes reciprocal empathy and mutual respect. Kymlicka (2002: 302) argues in favour of civility as a principle regulating inter-personal exchanges in liberal societies - also in terms of civil indifference towards difference (Young 1986) or civil inattention (Goffman 1972). Also authors writing outside the field of political 
philosophy agree on the normative value of civility, variously understood as a form of acknowledgment of the moral equality of human beings (Boyd 2006: 866), a synonym for ethical living in which dominant modes of socio-spatial inhabitance yields to marginal modes (Hage 2003: 147) or a form of compassion, empathy and tolerance towards others (Rucht 2011: 395).

In what follows, I shall further scrutinize the discursive use of the notion of civility as it shapes the use of a collective 'we' facing immigration-related issues in the case of Italy, which I now present also in relation to the research design adopted.

\section{The case study: Italy}

Italy has only recently become a country of immigration. Although statistically the turning point was in 1973, when immigrants first outnumbered emigrants (Pugliese 2002), the first considerable in-flow took place between 1984 and 1989 (Zincone 1998: 48). Besides being a relatively recent phenomenon, immigration to Italy has also been a relatively rapid one. On 1 January 2003, this presence accounted for $1,549,373$ people or $2.7 \%$ of the total population. A decade later, on 1 January 2014 , the figure was up to $4,922,085$ or $8 \%$ of the total population (source: ISTAT http://demo.istat.it/). Between 2003 and 2010, there was an average growth of $12.7 \%$ or 431,000 people a year (Ambrosini 2013: 139). It is this fact, along with its history of emigration, its small or negative population growth, the existence of a diffuse illegal labour market, the practice of frequent amnesty laws, and a public illprepared for the settlement of immigrants, which makes Italy - together with Greece, Spain and Portugal - a country representative of the so-called 'Mediterranean model of immigration' (King and Black 1997, Pugliese 2002, DeMaria Harney 2006). 
Politically, Italy experienced a major reshuffling in the early 1990s, after the judicial investigation Mani Pulite wiped out most of the traditional political parties which had governed the so-called First Republic (1948-1994), namely the Christian Democrats (DC) and the Socialists (PSI) (Burnett and Mantovani 1998). In the Second Republic, those parties which survived Mani Pulite have gone through major ideological changes with for instance the Communist Party (PCI) evolving into the Democratici di Sinistra (DS) and then into the present Partito Democratico (PD) - in line with mainstream social-democratic parties in Europe - and the neo-fascist MSI-DN evolving into the post-fascist Alleanza Nazionale (AN). Out of the ashes of the DC, two minor Christian parties have also emerged: the UDC (centre-right) and the PPI (centre-left). The major transformations associated with the Second Republic, though, were the appearance of Forza Italia (FI) in 1994 - the centre-right party led by the tycoon Silvio Berlusconi (Shin and Agnew 2008) - and, since 1990, the exponential rise of the Lega Nord (LN) (Agnew 2000) - a regionalist party claiming independence for the Italian North (Padania) which, under the current leadership, has campaigned nationally with an anti-immigration and anti-Europe agenda (Albertazzi and McDonnell 2015). Since 2013, a major political actor is also the Movimento 5 Stelle (M5S), a party created and led by an excomedian, Beppe Grillo, whose political views are generally characterized as Eurosceptic and populist, being rather ambivalent towards migration issues (Bordignon and Ceccarini 2013).

For reasons of brevity, in this paper I shall use the term 'rightist narrative' to identify the views of centre-right and right-wing political parties, and 'leftist narrative' to identify the views of the centre-left and left-wing parties. This semantic expedient obviously fails to capture variation within each group. Yet, my aim is not to follow closely which party said what during the parliamentary debates, but to identify narratives of nation facing immigration which, with differences in tone, were largely similar as between the two groups. 
When it comes to national identity, Italy has often been portrayed as a failed or unaccomplished nation (Graziano 2010), with various scholars, Italian included, pointing to the Italians' fragile sense of national identity (Galli della Loggia 1996, Bedani and Haddock 2000, Patriarca 2001). Among the most common reasons cited are the weakness of the state (Gentile 2010), the North-South divide (Schneider 1998), and the poor social capital and civic spirit (Putnam 1993).

Putnam's thesis has been very influential, even though it has been much criticized, theoretically (Mouritsen 2003), methodologically (Edwards 2010), and analytically (Bagnasco 1994, Sciolla 2004). Its intellectual resilience, though, is confirmed by the fact that it was already anticipated in previous classical studies on Italian democracy and society (Banfield 1958, Almond and Verba 1965) and that it continues to permeate contemporary debates on Italian national character (Tullio-Altan 1997, Ginsborg 2013). Yet, moving from the politological to the historiographical and from the civic to the civil, a different picture seems to emerge. According to Di Ciommo (2005: 34-35), during the first half of the $19^{\text {th }}$ century the idea of the Italian nation emerged closely associated with the project of republican constitutionalism, which in turn was based on ideals of modernity, freedom and civility. It was around this project that a sense of national identity flourished among the young educated elites of the peninsula (Di Ciommo, 2005: 29-30). Also for an important historian like Chabod (1951: 66), the Italian unification process was built around the conceptual triad nation-freedom-civility. In this context, civility stood for both technical and economic modernization and for higher stages in the historical process of civilization (Di Ciommo 2005: 48-49), thus confirming Elias's (1939 [2000]) reading of this concept.

Having been sidelined by liberal and Fascist Italy, republican constitutionalism was fully acknowledged in the post-war period. Interestingly, the new republican Constitution almost eschewed the term 'nation', preferring instead the term 'republic', thus signalling a civic 
conception of the country (Rossi 2012: 246ff). Thus, it is not surprising that when a public debate on Italy's national identity emerged again in the 1990s (Patriarca 2001) - after a period in which such a topic was considered taboo due to the Fascist legacy (Nevola 2004) it was framed around the idea of constitutional patriotism (Rusconi 1993). This civic understanding of the nation was then further reinforced, in political practices, under the presidency of Ciampi (Thomassen and Forlenza 2011). During the celebrations for the $150^{\text {th }}$ anniversary of Italian unification (2011), this understanding characterized the official rhetoric and, not surprisingly, it was reflected in the opinion polls, with $88.4 \%$ of respondents mentioning the approval of the Italian Constitution as a key event in the history of the country (Rossi 2012: 223, note 2).

To illuminate the link between civility and nation, this article analyses political debates on immigration-related issues, held in both the Camera (Lower House) and the Senato (Upper House) of the Italian Parliament, between 1986 and 2014. In 1986, the Parliament approved what is usually considered (Allievi 2014: 3) as the first immigration law (Law 943/1986), which regulated the entry of labor migrants and passed the first 'amnesty' of irregular immigrants. This was then followed in 1990 by the so-called 'Martelli Law' (Law 39/1990) and, eight years later, by the 'Turco-Napolitano Law' (Law 40/1998). Both were approved by a centre-left majority and both regularized undocumented immigrants and set an annual quota for newcomers. The Turco-Napolitano Law also adopted for the first time integration measures aimed at empowering migrants' rights (e.g., equality of access to the national health and education systems, right to family reunification and free Italian language courses). In 1992, the Parliament also approved the current nationality law (Law 91/1992), confirming the principle of ius sanguinis over ius soli. ${ }^{2}$ Finally, in 2002, a centre-right majority approved the 'Bossi-Fini Law' (Law 189/2002), a rather restrictive law both in terms of entry requirements and conditions for stay, which is still in force today, although 
partly softened by judicial intervention, in particular, of the Constitutional Court (Zincone 2006, Di Martino, Biondi Dal Monte et al. 2013).

Data was collected in Italian ${ }^{3}$ and coded via an 'analytic induction' approach (Crang, 1997) which, echoing grounded theory, relies on the iterative process of going back and forth between original data and theoretical concepts in order to reach successively more abstract categorizations.

\section{Civility: a 'rightist' narrative}

In the political speeches by right and centre-right party representatives, civility is mobilized as a way of reaffirming the national boundary, both materially (in the sense of keeping migrants out of the national territory) and symbolically (in the sense of preserving an ethno-cultural community). While the material exclusion of migrants relies on an understanding of civility in terms of dignified living conditions, the symbolic preservation of the nation operates with a 'civilizational' understanding of civility. Although both viewpoints coexist from the beginning, the tendency is for the former to prevail in the first decade or so of the parliamentary debates, when the main concern was about migratory flows, and for the latter to gain momentum when a conspicuous immigrant population began to settle in Italy and, accordingly, issues of integration become more prominent. In what follows, I shall discuss these two narratives with the support of illustrative excerpts from the Parliamentary debates.

Welcoming, dignity, and rights: the farcical role of civility 
In 1990, the Parliament, dominated by a centre-left majority, passed the so-called Martelli Law (n.39/1990). This law granted an 'amnesty' by regularizing about 240,000 undocumented migrants and offered a legal channel of immigration based on an annual quota. It also empowered migrants with rights, as well as obligations, and regulated their working conditions. It issued sanctions against migrant smugglers and traffickers and, for the first time, it reformed the asylum law, making it possible for non-Europeans to seek asylum in Italy (Finotelli and Sciortino 2009).

Generally perceived as a law empowering immigrants' rights, it was opposed by the Republican Party (PRI), a member of the centre-left government coalition, and the Movimento Sociale Italiano-Destra Nazionale (MSI-DN), a far-right party. While the opposition of the latter is rather understandable, the opposition of the PRI is less so. Traditionally a centre party, leaning towards conservative rather than progressive positions, during the parliamentary debate on the Martelli Law the PRI was accused by the leftist parties of aligning with 'rightist' views. Opposing the amnesty in the name of the 'rule of law' (lo stato di diritto), the PRI voted against the Martelli Law.

In the political rhetoric of the PRI, as well as in the MSI-DN's, civility is accompanied by notions of welcoming, dignity, and rights. Below is a passage of the intervention by Gianni Ravaglia, MP for the PRI, during the debate on the Martelli Law:

The answer does not consist in liberalizing, but in programming and making compatible the migratory process with the economic and living conditions and the conditions of civility which we can offer to the immigrants. [...] For the republicans, the defence of the rule of law is an essential and inalienable principle. [...] Ours is therefore a choice of civility aimed at guaranteeing a civil living-together to those who obtain the immigration 
visa, so they can enjoy all the rights and also meet the proper duties of a civil country like ours (Camera, 15/02/1990: 48849).

What we should understand by the phrases 'conditions of civility' and a 'civil livingtogether' (convivenza civile) is further amplified in another passage of the parliamentary debate by Danilo Poggiolini, also MP for the PRI:

To the foreign workers in our country should be given the possibility to live in a dignified way, to have a secure job, a house, social and health assistance appropriate to a civil country like ours (Camera, 20/02/1990: 49155)

Further reinforcing this argument, Massimo Massano, MP for MSI-DN, adds: our coloured brothers come to Italy to do activities completely unsuitable to the civil conscience of a people who wants to define itself as such (Camera, 20/02/1990: 49181).

In these interventions, civility is defined in terms of rights and dignity, clearly resonating with a liberal understanding. Yet, a closer look at the above rhetoric, also in the light of the oppositional stance of the PRI and MSI-DN to the Martelli Law, suggests that civility here works as a rather illiberal boundary mechanism (Zimmer 2003). On the one hand, there is indeed the Italian nation-state portrayed as a civil space. On the other hand, there are the immigrants who, if we allow them to come here, would not be able to conduct a civil life, being unable to secure a job, to live in decent houses, and to fully benefit from the welfare and health system. Civility is thus used to construct two opposing identity categories, the civil 'us' and the not-quite-civil 'them' - purposely ignoring how many of 'us' also face conditions of not having a secure job or living in decent housing. Interestingly, however, this 
distinction is not cast in culturalist terms - as if it were their cultures which prevented them from acting civilly - but builds on the allegedly limited resources of the nation-state. Imbued with a chauvinist welfare view (Andersen and Bjørklund 1990), which prioritizes the national members versus the rest, this position is obviously against extending equal rights to 'them', as proposed by the Martelli Law, but is about keeping 'them' off. In a passage of the parliamentary debate, this position emerges quite clearly:

we have the arrogance of transforming, with a legal act, an immigrant-very often a clandestine - into a subject entitled to civil rights, giving him [sic] those rights which are common to any citizen of our country. This is a vain effort (Guido Martino, PRI Camera, 21/02/1990: 49289).

Appealing to Italy as 'the homeland of law' and 'the light of reason', this position rejects, in very illiberal terms, that immigrants should be entitled to the same rights as the Italian citizens. This would be against the 'rule of law', which for the PRI is the essence of civility. Thus, from this perspective, civility is not a universal principle informed by a liberal view on equality, but a 'national' principle, being predicated on the law of a given nationstate. Moreover, exactly because of this national inflection which distinguishes between national citizens and foreigners, civility is also cast in a zero-sum game. The extension of rights to 'them' would necessarily impinge upon the quantum of 'our' rights:

If it is righteous to give civil and human dignity to immigrants, it is also righteous that the dignity given to them is not at the expense of Italian citizens (Gastone Parigi, MSIDN - Camera, 15/02/1990: 48870) 
and again, from another speaker:

Extracommunitarians are welcomed, given the tradition of respect and democracy which our civility and our culture claims. However, when the number reaches certain levels, the natives feel threatened. [...] The explosive phenomenon of extracommunitarian immigration can generate huge damage to civil living-together in our country (Danilo Poggiolini, PRI - Camera, 15/02/1990: 48907)

A civil living-together can only be guaranteed if the majority group remains as such. Far from a neutral term, civility 'freezes' the nation (Suvarierol 2012), it perpetuates the exclusive entitlement to the national space by the majority group, closely in line with Hage's (2000: 48) argument that nationalism is defined by the mastery of the national territory by an ethnic core.

\section{'Civilizational' civility}

If civility as a dignified life is used as a way to keep 'them' off, its 'civilizational' reading sets the culturalist framework within which immigrants have to integrate. Civility still acts as a boundary mechanism, but in a symbolic rather than material way aimed at preserving the conflation between the identity of the majority group and national identity.

In the parliamentary debates, this 'civilizational' trait was conveyed by recalling and appealing to the longevity of the nation and its glorious past, like for instance in this intervention by Olindo del Donno (MSI-DN), during the debate on the Martelli Law: 
Not civil, but incivil country or ancient civility lost in time and never again regained. This has also happened because of parties which, rather than loving and honouring the motherland, talk of civility coming not from East but from those lands whose civility depended on us [...] It is that part of Africa which we redeemed, which became great, civil and august thanks to us. [...] We will therefore campaign to bring civility back to Italy; we want to welcome foreigners not only by opening to them the doors of law, civility, the Roman spirit (Romanità), and religion, but also acknowledging their right to a motherland (Camera, 15/02/1990: 48875).

The leftist parties and their support for a multicultural society are here criticised for dismantling Italy's civility. The implicit assumption is that diversity clashes with civility, the latter being framed in culturalist terms, associated with the history, traditions and religion of an ancient and glorious people, as also observed during other parliamentary debates: "we are a people with 2,000 years of history, we have spread civility and taught hospitality" (Roberto Menia, AN - Camera, 30/09/1997: 49); “our ancient people have brought civility to the world" (Maria-Grazia Siliquini, AN - Senato, 27/01/1998: 14); "we have fecundated the Western world with the culture of Roman Law and Christianity" (Luca Volonté, UDC Camera, 04/06/2002: 17). In these interventions, civility works to elevate Italy's culture and downplay migrants' cultures, as again observed by Del Donno during the same debate on the Martelli Law:

It would be very nice to live in a multicultural society, but if only those other cultures were able to produce and exchange with us products which even if they do not match ours, at least come close to doing so. It would be very hard to imagine that an African 
could write a book like The Prince by Machiavelli or the books on Germany by Tacitus [...] (Camera, 21/02/1990: 49295)

Given this civilizational superiority, it is not surprising that integration is framed as a one-way process, with clear desires to educate 'them' in our rules and principles - in a classic civilizational spirit - particularly when 'they' are Muslims:

In Milan there are Islamic schools [...] and the respect and tolerance we demonstrate to their culture is often perceived as an acceptance of any form of behaviour, even in open contrast with our civil rules. These are transgressive behaviours often induced by the sudden and traumatic clash against Western civilization by people who, in their impact with our social organization, need firm and secure guidance (Calogero Sodano, UDC Senato, 27/06/2002: 32).

In this intervention, pronounced during the debate on the Bossi-Fini Law (n. 189/2002), the culturalist dimension of civic integration is clearly apparent. This was not an isolated case, but it represented a common stance of centre-right and right parties which, following a generalised trend in Europe (Sayyid and Vakil 2008), has increasingly found in Muslims the target of their integrationist policies.

Interestingly, within this civilizational perspective, a "civil living-together" is no longer expressed as dignified life, but as integration into a given, non-negotiable legal and cultural framework:

Our main goal is to create a civil living-together which respects the needs of the others, which guarantees the righteous welcoming of those who come to Italy to work, those who 
respect the law, those who accept our culture, who wants to integrate with us in our context (Ignazio La Russa, AN - Camera, 20/09/2006: 14).

Civility, even in this case, allows the majority group to reaffirm its monopoly over the meanings of the nation, preventing any renegotiation of its symbolic boundaries.

\section{Civility: a 'leftist' narrative}

In the reading of left and centre-left parties, civility is first and foremost grounded in the rule of law. Yet, contrary to the rightist view, it is international law, informed by universal human rights, which comes to prominence. Accordingly, the law is not used to keep 'them' off, but to empower 'them'. Such a view is obviously associated with a different national imaginary, open to diversity and plurality, which is apparent from the beginning in the parliamentary debate and is to characterize the leftist discourses throughout the survey period. Interestingly, the same notions used by the rightist speakers - rule of law, respect, and dignity - also return in the way civility is articulated by the leftist speakers. Yet, in this case, they are deployed to overcome rather than demarcate the national boundary, as the very distinction between 'us' and 'them' fades away within this narrative.

Here, for instance, how the proponent of the Martelli Law justified his bill:

I think we all agree on the necessity to adjust Italy to the needs of a multi-ethnic society and this requires commitment, intelligence and a culture open to solidarity, novelty, diversity, and foreignness [...]. I believe a civility test is the present government's 
attempt to create space, conditions and respect for the foreign citizen within the Italian society (Claudio Martelli, PSI - 20/02/1990: 49114)

Contrary to the political right, the leftists accept the demographic transformation of the country and measure civility in terms of creating space for the newcomers, who are no longer asked to integrate by respecting 'us', as the opposite is instead true. Civility also ceases to be a test for assessing their integration and becomes, on the contrary, a test for assessing the government's capacity to guide the nation through this demographic change. Here and elsewhere, civility is also hardly defined in 'national' terms (e.g., 'Italian civility' or 'our civility'), but it is heralded as a moral referent. 'Civil conscience' and 'civil living-together', which were also heard in the discourses of the rightists, now lose their culturalist tone and become imbued with legal empowerment, like for instance in this passage by Rosario Olivo (DS), during the debate of the Turco-Napolitano Law (n.48/1990):

Right to work, right to healthcare, right to family reunification, right to education, right to public housing. It is on fundamental social rights that the game of integration of immigrants is played in the Western world [...] Dear colleagues, our responsibility is to create those conditions which in the future can make a civil living-together possible (Camera, 30/09/1997: 41).

Central to this new civic conception of living-together is the notion of citizenship:

We need to provide to all citizens - Italians, but obviously also foreigners - living and economic conditions which respect their dignity as persons [...]. Whether we like it or not, we are transforming into a global, plural and multi-ethnic society. Thus, to win the 
challenge of globalization I believe is essential to offer our citizens a proposal of security and integration based on the notion of citizenship. If we can encourage belonging to a civil community, based on the rediscovery of common and shared values, on the representativeness of interests through democratic institution, on a relationship of mutual responsibility between citizens and the state [...] then the new and the diverse can generate less fear (Maria-Pia Valetto Bitelli, PPI - Camera, 23/10/1997: 52)

In this passage during the debate on the Turco-Napolitano Law, respect, dignity and rule of law serve not to exclude, like in the rightist narrative, but to encourage a new inclusive pact between the state and its citizens. Reproducing the same process as described in the 'civic turn' (Joppke 2008), democracy ceases to be a mere procedural framework and comes to substantiate this pact, centred on the notion of citizenship, as well as on common and shared values (i.e., constitutional values). As also observed for the 'civic turn' (Joppke and Morawska 2003: 20), a post-national de-coupling between state (political) and nation (culture) now becomes salient, as clearly illustrated in this excerpt by Giorgio Gardiol (Verdi), again during the debate on the Turco-Napolitano Law:

It is about re-elaborating the idea of citizenship, separating it from the idea of nationality and incorporating those rights which a civil conscience regards as universal (Camera, 23/10/1997: 83).

This focus on post-national citizenship should not cause the reader to think that the leftist narrative aims to move beyond the nation altogether. The nation remains in place as a sociosymbolic register. Yet, it is indeed re-written in its civic form, as clearly illustrated in the two following quotes from the 2009 debate on nationality law: 
Inside this immigration process there is not only the idea of a country and a nation, but there is the idea of building a new future and a new idea of nation [...]. So what is the idea of nation we have? Is it only patriotic love or is there also a civic consciousness of this nation, constituted by a capacity to look at its statehood, to cater for the public domain and to inhabit a set of shared values? This is the idea of the modern state, otherwise we return to an old idea of the nation state, which is closed, unable to welcome those who knock at our door [...]. Citizenship is really for us the route through which to measure our civil and legal capacity as nation, our identity as a people who must consider foreigners who demand citizenship as 'new Italians' (Sesa Amici, PD Camera, 22/12/2009: 70).

Identity is not immobile; it is something alive which is built everyday. It is the patient and persistent construction of a new patriotism in the name of openness, respect of rules and duties along with rights for all. In the name of our Constitution and the values which sustain it. This is the right battle, which helps to build a better country, also inhabited by new Italians, who with us contribute towards building a national identity projected into the future (Dario Franceschini, PD - Camera, 22/12/2009: 33)

When analysed against the literature on the 'civic turn' and in particular the criticism related to it being a covert form of re-nationalization (Mouritsen 2006, Kostakopoulou 2010, Jensen 2014, Larin 2015), these two excerpts seem to suggest something else. What is indeed missing from them is the boundary mechanism (Zimmer 2003). In other words, the deethnicization of 'us' does not come at the expense of a culturalization of 'them' (Gressgård 2010). The "thinness that thickens" (Mouritsen 2008: 6) hardly finds a place here. The civic 
nation of this leftist narrative is not aimed at preserving the national boundaries and, with them, the identity boundaries of the majority group. On the contrary, it aims to open these boundaries, making the nation a plural, inclusive, shared project. This also seems evident in another passage of the parliamentary debate, occasioned by the racist insults of a Lega Nord's MP to the Italian black Minister Cécile Kyenge: ${ }^{4}$

We need to start a journey of education to civility. It is a civility which we still have to reach [...]. This is a common journey; it is not an adaptation of them to our principles, but of us to our principles - all, a common and inclusive journey [...]. To educate to civility: it is from this simple concept which the future of our society relies on (RosaMaria Di Giorgi, PD - Senato, 18/07/2013: 9)

Here civility is the aim of the civic nation, a common journey of all its members, without distinction of backgrounds. It is not something given, but a shared endeavour; it is not about being the same, but being together or doing something together (Mouritsen 2008: 27). True, this journey takes place within a cultural framework defined by constitutional principles, i.e. the liberal principles of equality, social justice, and individual rights, which are not open to negotiation. This caveat standing, civility is not, however, used to generate two opposite essentialized cultures: 'ours', civil and progressive; 'theirs', regressive and backward (Mouritsen 2008: 12). Or better, this does happen, but not in relation to 'we' Italians and 'they' immigrants. It is an opposition applied within the political debate, with the leftists accusing the rightists of being 'incivil':

The colleagues of the Northern League live outside history and outside our ethic and legal civility (Raffaele Cananzi, PD - Camera, 19/11/1997: 117) 
With this act [related to the Bossi-Fini Law] you make a frightening jump, outside the illustrious legal civility which our country can be proud of in the world (Carlo Leoni, DS - Camera, 11/11/2004: 106)

As the rightists accused the leftists of destroying 'our' civility, in a narrative imbued with references to the glorious deeds of the Italian people, their religion and their Roman past, so the leftists retaliated by re-directing the accusation in a narrative which recasts 'our' civility in universal moral terms. These are not only two competing narratives of civility, but indeed of nation. While in the first case, civility is discursively activated to keep a boundary mechanism in place, which preserves the authoritative power of the majority group over the symbolic content of the nation, in the second case civility is rendered into a principle regulating inter-personal exchanges within a nation re-imagined as the coming together of citizens.

\section{Conclusion}

The present article has analyzed the discursive use of the notion of civility and its adjectivization in the case of Italy's parliamentary debates on immigration-related issues. I have shown how this notion intervenes in the construction of national imaginaries by both 'rightist' and 'leftist' parties, producing two clearly distinct outcomes. On the one hand, it reproduces the conflation between national identity and the identity of the majority group, thus preserving the authority and entitlement of the latter over the meanings of the former. Discursively, this is done by mobilizing civility in liberal, 'civic' terms, i.e. by recalling the 
duty of welcoming others and providing them with dignified living conditions, and in 'civilizational' terms, by imbuing civility with the glorious past of the nation vis-à-vis other, inferior cultures. In both cases, the end result is the reproduction of an exclusive, ethnocentric nation, closed to those who cannot meet a 'civil' condition.

On the other hand, civility is imbued with what Boyd (2006: 874) would call an acknowledgment of the moral equality of human beings. This also resonates with a liberal, 'civic' understanding of civility. In fact, it likewise relies on notions of individual rights and dignity. Yet, despite the common content, the boundaries mechanisms (Zimmer 2003) are different. In this narrative, civility is about overcoming the distinction between 'us' and 'them' so that a new common 'we' can be built around the notion of post-national citizenship. There is no demand to integrate one part with another, because all the affected parties have to rediscover a civil living-together based on the constitutional principles of justice, equality and non-discrimination. The end result here is the production of an inclusive nation, open to everybody who wants to join the common journey towards civility.

How do these findings speak to the current debate on the 'civic turn'? I think there are two main points worth mentioning. First, while a considerable amount of scholarship has explored the liberal convergence across countries, relatively few studies have investigated this convergence across political parties within the same country (Alonso and da Fonseca 2012, Hinnfors et al. 2012, Jensen and Mouritsen 2015). Findings for Italy suggest that this is a useful exercise, as it permits further amplification of the meanings of the 'civic turn'. In fact, as mentioned above, convergence towards a shared liberal, civic narrative in political discourses might hide divergent boundary mechanisms. Second, and closely related to this point, although there is evidence that the deployment of a civil vocabulary can stand for a renationalization of politics, this is not the only story. The post-national is not 'obsolete' (Mouritsen, 2012: 87). On the contrary, it continues to illuminate the path of those political 
actors who wish to steer the nation away from its ethno-cultural past and present. In this view, the civic turn is not synonymous with renewed ethno-centric assimilation (Kostakopoulou 2010: 949), but with a national revival which everybody is called upon to accomplish. In this sense, the rise of the 'civil' nation appears as a Janus-faced construct, stranded between a genuine attempt to re-write the nation in inclusive terms and a staunch defence of the symbolic and material boundaries of an exclusive nation by the ethno-cultural majority.

A final caveat applies. To what extent does the difference in political narratives of nation translate in different policies? There is indeed some evidence that, in the case of Italy, the tendency has been for immigration and integration policies to converge (Zincone 2006: 348). If this is the case, further research is needed to explore the reasons for this mismatch as well as the conditions which would allow for the post-national, civic discourse to translate into consistent policies.

\section{References}

Agnew, J. 2000. "The road to Padania: the Northern League and Italian regionalism." International Journal of Urban and Regional Research 24(1): 227-231.

Albertazzi, D. and D. McDonnell 2015. Populists in power. London, Routledge.

Allievi, S. 2014. "Immigration, religious diversity and recognition of differences: the Italian way to multiculturalism." Identities 21(6): 724-737.

Almond, G.A. and S. Verba 1965. The Civic Culture. Princeton: Princeton University Press. 
Alonso, S. and S.C. da Fonseca 2012. "Immigration, left and right." Party Politics 18(6): 865-884.

Ambrosini, M. 2013. "'We are against a multi-ethnic society': policies of exclusion at the urban level in Italy." Ethnic and Racial Studies 36(1): 136-155.

Andersen, J.G. and T. Bjørklund 1990. "Structural changes and new cleavages: The Progress Parties in Denmark and Norway." Acta Sociologica 33(3): 195-217.

Andreouli, E. and J.E. Stockdale 2009. "Earned citizenship: Assumptions and implications." Journal of Immigration, Asylum and Nationality Law 23(2): 165-180.

Antonsich, M. 2009. "National identities in the age of globalization. The case of Western Europe." National Identities 11(3): 281-299.

Antonsich, M. 2012. "Exploring the demands of assimilation among white ethnic majorities in Western Europe." Journal of Ethnic and Migration Studies 38(1): 59-76.

Antonsich, M. 2015. Nations and nationalism. Companion to Political Geography. J. Agnew, V. Mamadouh, A. Secor and J. Sharp. Oxford, Wiley-Blackwell: 297-310.

Bader, V. 2005. Ethnic and religious state neutrality: Utopia or myth. Changing the basis of citizenship in the modern state. H.G. Sicakkan and Y. Lithman. Lewiston, Edwin Mellen: 161-198.

Bagnasco, A. 1994. "Regioni, tradizione civica, modernizzazione italiana: un commento alla ricerca di Putnam." Stato e Mercato 40(april): 93-103.

Banfield, E.C. 1958. The moral basis of a backward society. New York: Free Press

Barber, B.R. 1984. Strong democracy. Berkeley, University of California Press.

Bauböck, R. 2002. "Farewell to Multiculturalism? Sharing Values and Identities an Societies of Immigration." Journal of International Migration and Integration 3(1): 1-16.

Baumeister, A. 2007. "Diversity and unity. The problem with 'constitutional patriotism'." European Journal of Political Theory 6(4): 483-503. 
Baumgarten, B., D. Gosewinkel and D. Rucht 2011. "Civility: introductory notes on the history and systematic analysis of a concept." European Review of History 18(3): 289312.

Bedani, G. and B. Haddock, Eds. 2000. The Politics of Italian National Identity. Cardiff, University of Wales Press.

Bordignon, F. and L. Ceccarini 2013. "Five stars and a cricket. Beppe Grillo shakes Italian politics." South European Society and Politics 18(4): 427-449.

Boyd, R. 2006. "The value of civility?" Urban Studies 43(5/6): 863-878.

Brown, E. 2003. "Rawls and the Duty of Civility." Locations of the Political 15(1): 1-18.

Brubaker, R. 1999. The Manichean myth: rethinking the distinction between 'civic' and 'ethnic' nationalism. Nation and National Identity H. Kriesi, K. Armingeon, H. Siegrist and A. Wimmer. Zürich, Rügger: 55-71.

Burnett, S.H. and L. Mantovani 1998. The Italian Guillotine. Lanham, Rowman\&Littlefield.

Calhoun, C. 2007. Nations matter. London, Routledge.

Chabod, F. 1951. Storia della politica estera italiana dal 1870 al 1896. Roma-Bari, Laterza.

Colombo, A. and G. Sciortino 2004. Gli immigrati in Italia. Bologna, il Mulino.

DeMaria Harney, N. 2006. "The alternative economies of emigration and immigration, the Real and the constitution of Italian nation spaces." Mobilities 1(3): 373-390.

Di Ciommo, E. 2005. I confini dell'identità. Roma-Bari: Laterza.

Di Martino, A., F. Biondi Dal Monte, I. Boiano and R. Raffaelli. 2013. The criminalization of irregular immigration. Pisa: Pisa University Press.

Edwards, L. 2010. "Re-thinking Putnam in Italy: The role of beliefs about democracy in shaping civic culture and institutional performance." Comparative European Politics 8(2): $161-178$

Elias, N. 1939 (2000). The civilizing process. Oxford, Blackwell. 
Faist, T. 2009. "Diversity - a new mode of incorporation?" Ethnic and Racial Studies 32(1): 171-190.

Favell, A. 2006. The nation-centered perspective. Dialogues on migration policy. M. Giugni and F. Passy. Lexington, Lexington books: 45-56.

Finotelli, C. and G. Sciortino 2009. "The importance of being southern: The making of policies of immigration control in Italy." European Journal of Migration and Law 11(2): 119-138.

Galli della Loggia, E. 1996. La morte della patria. Bari, Laterza.

Gentile, E. 2010. Né stato né nazione. Roma-Bari, Laterza.

Ginsborg, P. 2013. "Civil society in contemporary Italy" Journal of Modern Italian Studies 18(3): 283-295.

Goffman, E. 1972. Relations in public. New York, Harper\&Row.

Goodman, S.W. 2010. "Integration requirements for integration's sake? Identifying, categorising and comparing civic integration policies." Journal of ethnic and migration studies 36(5): 753-772.

Goodman, S.W. 2012. "Fortifying citizenship: policy strategies for civic integration in Western Europe." World Politics 64(4): 659-698.

Goodman, S.W. and M. Wright 2015. "Does mandatory integration matter? Effects of civic requirements on immigrat socio-economic and political outcomes." Journal of Ethic and Migration Studies 41(12): 1885-1908.

Graziano, M. 2010. The failure of Italian nationhood. London, Palgrave Macmillan.

Gressgård, R. 2010. Multicultural dialogue. New York, Berghahn Books.

Hage, G. 2000. White nation. London, Routledge.

Halikiopoulou, D., S. Mock and S. Vasilopoulou 2013. "The civic zeitgeist: nationalism and liberal values in the European radical right." Nations and Nationalism 19(1): 107-127. 
Hinnfors, J., A. Spehar and G. Bucken-Knapp 2012. "The missing factor: Why social democracy can lead to restrictive immigration policy." Journal of European Public Policy 19(4): 585-603.

Jacobs, D. and A. Rea 2007. "The End of National Models? Integration Courses and Citizenship Trajectories in Europe." International journal on multicultural societies 9(2): 264-283.

Jensen, K.K. 2014. "What can and cannot be willed: how politicians talk about national identity and immigrants." Nations and Nationalism 20(3): 563-583.

Jensen, K.K. and P. Mouritsen 2015. The politics of citizenship education in Denmark. 43rd ECPR Conference. University of Warsaw, ECPR.

Joppke, C. 2004. "The retreat of multiculturalism in the liberal state: theory and policy." The British Journal of Sociology 55(2): 237-257.

Joppke, C. 2007. "Beyond national models: Civic integration policies for immigrants in Western Europe." West European Politics 30(1): 1-22.

Joppke, C. 2008. "Immigration and the identity of citizenship: The paradox of universalism." Citizenship Studies 12(6): 533-546.

Joppke, C. 2010. Citizenship and immigration. Cambridge: Polity

Joppke, C. and E. Morawska 2003. Integrating immigrants in liberal nation-states. Toward assimilation and citizenship. C. Joppke and E. Morawska. New York, Palgrave: 1-36.

King, R. and R. Black (eds) 1997. Southern Europe and the new immigrations. Brighton, Sussex Academic Press.

Kohn, H. 1945. The Idea of Nationalism. New York, Macmillan.

Koopmans, R., P. Statham, M. Giugni and F. Passy 2005. Contested citizenship. Minneapolis, University of Minnesota Press. 
Kostakopoulou, D. 2010. "The anatomy of civic integration." The Modern Law Review 73(6): 933-958.

Kuzio, T. 2002. "The myth of the civic state: a critical survey of Hans Kohn's framework for understanding nationalism." Ethnic and Racial Studies 25(1): 20-39.

Kymlicka, W. 2001. Politics in the Vernacular. Oxford, Oxford University Press.

Kymlicka, W. 2002. Contemporary political philosophy. Oxford, Oxford University Press.

Kymlicka, W. 2011. "Multicultural citizenship within multination states." Ethnicities 11(3): 281-302.

Lægaard, S. 2007. "Liberal nationalism and the nationalisation of liberal values." Nations and Nationalism 13(1): 37-55.

Larin, S. 2015. Is it Really about Values? Civic Nationalism and Immigrant Integration. ECPR Annual Conference. Warsaw, ECPR.

Lattas, A. 2007. "'They Always Seem to be Angry’: The Cronulla Riot and the Civilising Pleasures of the Sun." The Australian Journal of Anthropology 18(3): 300-319.

Matejskova, T. 2013. "“But One Needs to Work!”: Neoliberal Citizenship, Work-Based Immigrant Integration, and Post-Socialist Subjectivities in Berlin-Marzahn." Antipode 45(4): 984-1004.

Mouritsen, P. 2003. "What's the civil in civil society? Robert Putnam, Italy and the republican tradition." Political Studies 51(4): 650-668

Mouritsen, P. 2008. Political responses to cultural conflict: Reflections on the ambiguities of the civic turn. Constituting communities. P. Mouritsen and K.E. Jørgensen. Basingstoke, Palgrave: 1-30.

Mouritsen, P. 2012. "The resilience of citizenship traditions: Civic integration in Germany, Great Britain and Denmark." Ethnicities 13(1): 86-109. 
Mouritsen, P. and T.V. Olsen 2013. "Denmark between liberalism and nationalism." Ethnic and Racial Studies 36(4): 691-710.

Müller, J.W. 2007. "Is Europe converging on constitutional patriotism?(and if so: is it justified?)." Critical Review of International Social and Political Philosophy 10(3): 377-387.

Nehring, H. 2011. "'Civility'in history: some observations on the history of the concept." European Review of History 18(03): 313-333.

Nevola, G. 2004. La nazione italiana: un ritorno dopo il congedo. In Una patria per gli italiani?, edited by G. Nevola, 19-49. Roma, Carocci.

Özkirimli, U. (ed) 2003. Nationalism and its Futures. London, Palgrave.

Patriarca, S. 2001. "Italian neopatriotism: debating national identity in the 1990s." Modern Italy 6(1): 21-34.

Pugliese, E. 2002. L'Italia tra migrazioni internazionali e migrazioni interne. Bologna, Mulino.

Putnam, R.D. 1993. Making Democracy Work. Princeton, Princeton University Press.

Rawls, J. 1993. Political liberalism. New York, Columbia University Press.

Reijerse, A., K. Van Acker, N. Vanbeselaere, K. Phalet and B. Duriez 2013. "Beyond the Ethnic-Civic Dichotomy: Cultural Citizenship as a New Way of Excluding Immigrants." Political Psychology 34(4): 611-630.

Reijerse, A., N. Vanbeselaere, B. Duriez and G. Fichera 2015. "Accepting immigrants as fellow citizens: citizenship representations in relation to migration policy preferences." Ethnic and Racial Studies 38(5): 700-717.

Rossi, M. 2012. Una sola moltitudine. Soveria Mannelli: Rubbettino.

Rucht, D. 2011. "Civil society and civility in twentieth-century theorising." European Review of History 18(03): 387-407. 
Rusconi, G.E. 1993. Se cessiamo di essere una nazione. Bologna: Mulino.

Sayyid, S. and A. Vakil 2008. Thinking thru' Islamophobia. Centre for Ethnicity\&Racism Studies, University of Leeds.

Schneider, J. (ed). 1998. Italy’s 'Southern Question'. Oxford, Berg.

Sciolla, L. 2004. Cultura civica e 'carattere nazionale'. Il caso italiano in prospettiva comparata. In Una patria per gli italiani?, edited by G. Nevola, 81-116. Roma, Carocci.

Shills, E. 1997. The virtue of civility. Indianapolis, Liberty Fund.

Shin, M. E. and J.A. Agnew 2008. Berlusconi's Italy. Philadelphia, Temple University Press.

Smith, A.D. 1986. The ethnic origins of nations. Oxford, Blackwell.

Smith, A.D. 1991. National Identity. London, Penguin Books.

Suvarierol, S. 2012. "Nation-freezing: images of the nation and the migrant in citizenship packages." Nations and Nationalism 18(2): 210-229.

Thomassen, B. and R. Forlenza. 2011. "Re-narrating Italy, reinventing the nation: assessing the presidency of Ciampi." Journal of Modern Italian Studies 16(5): 705-725.

Tullio-Altan, C. 1997. La coscienza civile degli italiani. Udine: Gaspari.

Türken, S., H.E. Nafstad, R.M. Blakar and K. Roen 2015. "Making Sense of Neoliberal Subjectivity: A Discourse Analysis of Media Language on Self-development." Globalizations(ahead-of-print): 1-15.

Van Houdt, F., S. Suvarierol and W. Schinkel 2011. "Neoliberal communitarian citizenship: Current trends towards 'earned citizenship'in the United Kingdom, France and the Netherlands." International sociology 26(3): 408-432.

White, M. 2006. "An ambivalent civility." The Canadian Journal of Sociology 31(4): 445460. 
Wright, M. 2011. "Diversity and the imagined community: Immigrant diversity and conceptions of national identity." Political Psychology 32(5): 837-862.

Xenos, N. 1996. "Civic Nationalism: Oxymoron?" Critical Review 10(2): 213-231.

Yack, B. 1996. "The myth of the civic nation." Critical Review 10(2): 193-211.

Young, I.M. 1986. "The ideal of community and the politics of difference." Social Theory and Practice 12(1): 1-26.

Zimmer, O. 2003. "Boundary mechanisms and symbolic resources: towards a processoriented approach to national identity." Nations and Nationalism 9(2): 173-193(121).

Zincone, G. 1998. "Illegality, enlightenment and ambiguity: A hot Italian recipe." South European Society and Politics 3(3): 45-82.

Zincone, G. (2006). "The making of policies: Immigration and immigrants in Italy." Journal of Ethic and Migration Studies 32(3): 347-375.

Zurn, C. 2013. "Political Civility: Another Illusionistic Ideal " Public Affairs Quarterly 27(4): 341-365.

\footnotetext{
${ }^{1}$ See also Müller (2007) for a variation of Joppke's argument informed by constitutional patriotism.

${ }^{2}$ Since 2001, various proposals for reforming the nationality law in the sense of the ius soli have been presented and the Parliament discussed two of these in 2005 and 2009, without reaching a final vote. At the time of writing this article, a new bill has been approved by the Camera and is awaiting further discussion in the Senato.
}

${ }^{3}$ All translations are by the Author and adopt a literary style, which might not always reflect fluency in English. 
${ }^{4}$ In July 2013, Roberto Calderoli, MP for the LN, made openly racist comments on Kyenge, Minister for
Integration. The incident was widely debated in the political and public sphere and led to a judicial sentence. 